\title{
The Big 5 Personality and Body Image in Cosmetic Surgery Applicants in Esfahan
}

\author{
Simin Danesh ${ }^{1}$, Elham Foroozandeh Ph.D. ${ }^{2^{*}}$ \\ 1- Department of Psychology, Islamic Azad University, Isfahan Branch, Iran. \\ 2- Department of Psychology, Naein Branch, Islamic Azad University, Iran.
}

\begin{abstract}
The purpose of this study was to investigate the relationship between the big five personality and body image in applicants for cosmetic surgery in Isfahan. This research project design was a correlation type and the statistical population included applicants for cosmetic surgery in the second half of 2014 and The first six months of 2015 in Isfahan. According to this purpose, a sample of 315 patients ( 238 females and 77 males) aged between 16 and 53 years old was selected through convenience sampling method among applicants for cosmetic surgery. Measurement tools of this research included Costa \& McCrae's Revised NEO-Five Factor Inventory, short form (NEO-FFI -1993) and Cash's Multidimensional Body-Self

Relation Questionnaire (MBSRQ-1997). Data analysis by Pearson correlation coefficient and multiple regression showed a significant positive correlation between a number of personality traits and body image dimensions $(\mathrm{p}<0.001)$. Also, the results of regression showed that among personality traits only conscientiousness could predict $2.7 \%$ of body image changes. According to these findings, conscientiousness may play a significant role in the tendency of individuals to perform cosmetic surgery.
\end{abstract}

Keywords: Body Image, Five Factor of Personality, Cosmetic Surgery. 


\section{هنج عامل بزركى شخصيت و تصوير بدنى در متقاضيان عملهاى جراحى زيبايى شهر اصفهان}

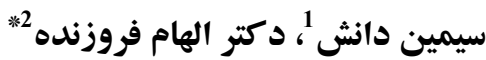

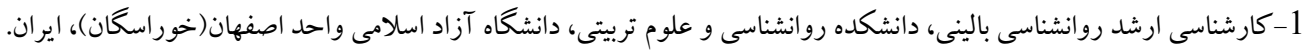

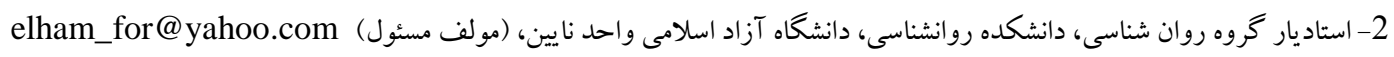

\section{جكيده}

يزّوهش حاضر با هدف بررسى روابط جند گانه ميان ينج عامل بزرك شخصيت با تصوير بدنى در متقاضيان عمل هاى جراحى

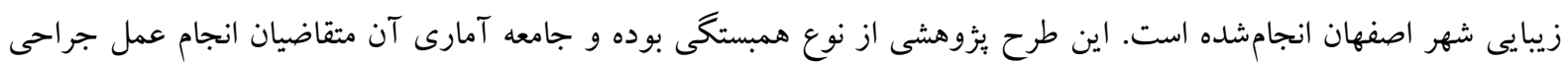

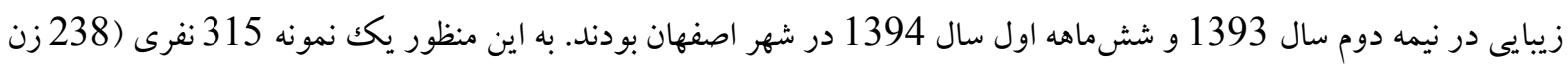

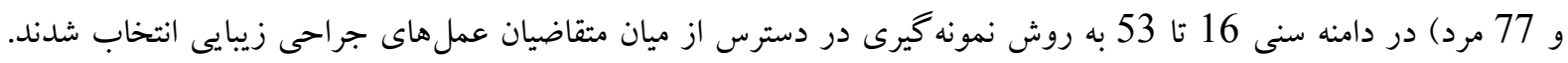

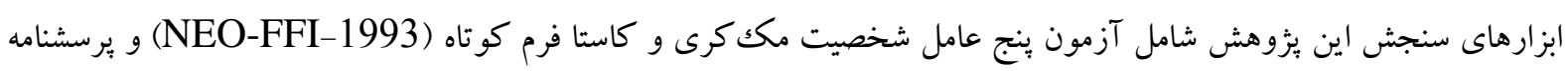

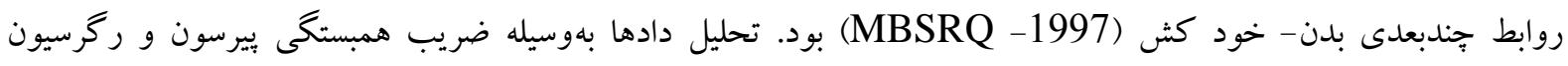

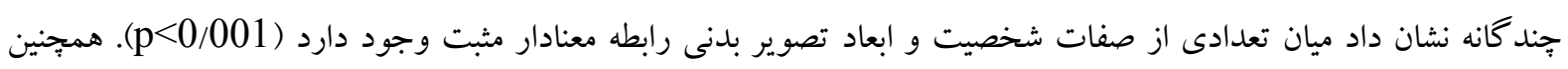

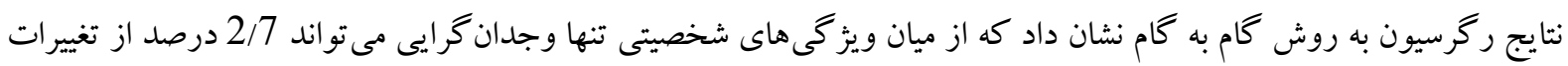

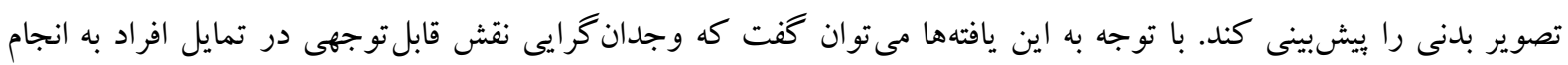
عمل هاى جر احى زيبايى بازى مى كند. كليد وازهها: تصوير بدنى، ينج عامل شخصيت، جراحى رئى زيبايى. 
از آن، در سالهاى 1930 تصوير تن توسط مطالعات

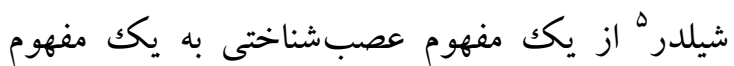
روان بويشى تبديل شد (كش و اسمولاكى، 2011). دهه 1990 نقش محورى در تكامل مفهوم تصوير تن

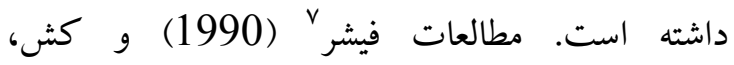
يروزينسكى و تامسون^ (1990) در زمينه مفهومبندى، ارزيابى و بررسى آسيبشناختى تصوير تن نقش ونش بسزايى داشتهاند (به نقل از كش و اسمولاكك، 2011). نارضايتى از تصوير بلدنى در ابتداى نوجوانى با

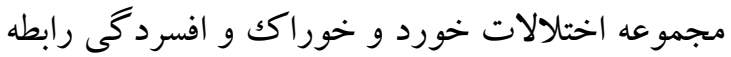
دارد (تامسون و اسمو لاكك، 2009؛ ضيغمىمحمدى و و مزده، 1390). اختلالات تصوير تن در نوجوانان دختر

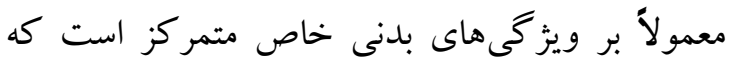

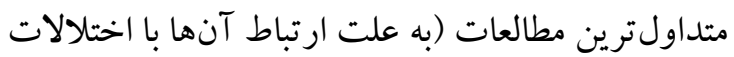
خورد و خوراك) شامل نارضايتى از وزن و شكل بدن مىشود (فيوزنر، تونسنت و و همكاران، 2007)؛ اما

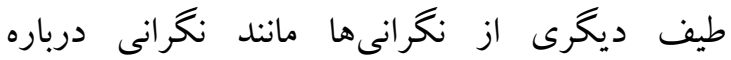
ويزّى هاى جهرهاى، ظاهر بوست، عضلانى بودن، تناسب اندام و قدرت بدنى در ارتباط با تصوير تن در دختران وجود دارد (اسمولاكك، 2004). نارضايتى از تصوير تن بهعنوان انخيزه اوليه براى

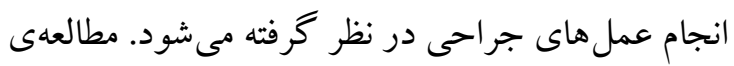
متقاضيان جراحى زيبايى نشان داده است كه قبل از عمل جراحى، نارضايتى از تصوير تن به مقدار زيادى

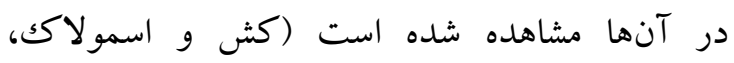

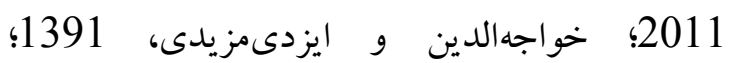
بنى اسدى، 1391). حجم زيادى از مطالعات، رضايت متقاضيان عمل هاى جراحى زيبايى را تأييد مى كنند، در حالى كه اين رضايت در افراد مبتلا به اختلال بدريختى ريتى رئل
بر اساس مطالعات بيشين به نظر مىرسد تصوير تن 'نقش اساسى در جستجوى عملهاى زيبايى دارد. طى جند سال اخير، نگگ انىهاى بيماران را در مورد تصوير تنشان قبل و بعد از عمل جراحى زيبايى مورد مطالعه قرارگرفته است. همانطور كه نارضايتى از تصوير تن مىتواند انخيزه افراد را براى انجام عملهاى

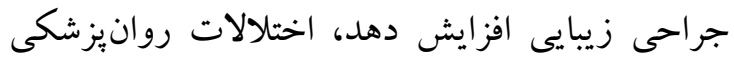
كه بهوسيله اختلال در تصوير تن شناخته مى شوند مانند اختلال بدريختى بدن و اختلالات خورد و خوراك، لهن

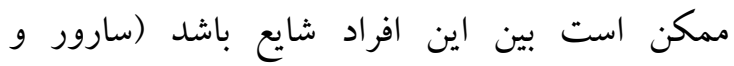
كررند، 2004) - (200).

تصوير بدنى عموماً به عنوان (اتصويرى كه از بدن در ذهن وجود دارد و به عبارتى، طريقى كه بدن به بهون ادراكك مىشود) تعريف مىشود. تصويرتن، شيوهاى است كه يكك فرد خود را مفهومسازى مى كند و بيشتر به جنبهاى ناهشيار و جسمانى مربوط مىشود (يرى زاده، 1391). تصوير بدنى غالباً به عنوان يكك ساختار جند بعدى شامل شناخت، هيجان و عناصر رفتارى شناخته مىشود. نارضايتى از تصوير تن، دربر گيرنده تفاوت بين ويز گیىهاى فعلى بدن فرد با آنجه در حال

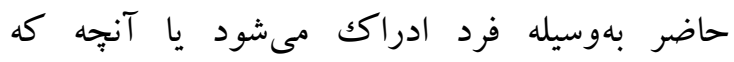

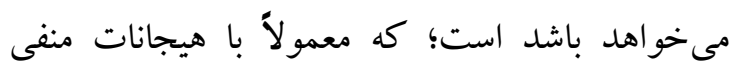
همراه است (كش، 1998؛ كش 1994؛ به نقل از بلبلى، حبيبى و رجبى، 1392). مطالعات اوليه در مورد تصوير تن تحت تأثير

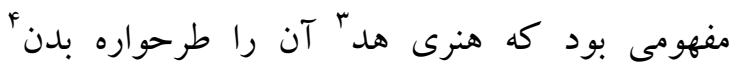
مىناميد؛ يكك مكانيزم عصبى فرضى كه در نتيجه عدم بهم هماهنگى اعضاى بدن در ذهن فرد ايجاد مى شود. بعد

1 Body Image

2Sarwer\&Crerand

3 Henry Head

4 The Body Schema 
روش

روش يخوهش، جامعه آمارى و نمونه: روش

آمارى يزٔوهش حاضر از نوع همبستخى است. متغير بيش بين بز وهش بنج عامل شخصيت و متغير ملاكك

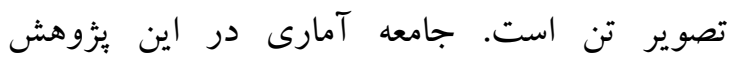
متقاضيان انجام عمل جراحى زيبايى در نيمه دوم 1393 تا ششماهه اول 1394 در شهر اصفهان بود.

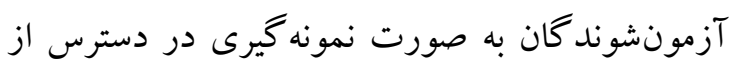
ميان مراجعين كلينيكهاى جراحى زيبايى انتخاب شدند و واجد سه ملاكك زير براى ورود به مطالعه بودند: 1- عمل جراحى آنها از نوع عملهاى تهاجمى' باشد و نه سريايى، 2- متقاضى بهواسطه مشكل بز شكى جدى براى انجام عمل مراجعه نكرده باشد و عمل جراحى صرفاً جنبه زيبايى داشته باشد و

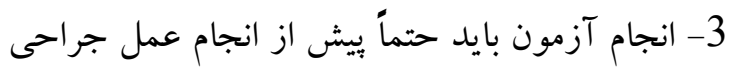
صورت مى گرفت، زيرا تحقيقات نشان دادهاند نتايج عمل جراحى زيبايى مىتواند بر ميزان رضايتمندى افراد از تصوير بدنىشان تأثير داشته باشد (اسدى، رئائ صالحى و همكاران، 1392؛ زمانى و فضيلت يور، 1392؛ بنى اسدى، 1391). در اين ئزوهش هم مردان و هم زنان متقاضى جراحىهاى زيبايى شركت داشتند. براى جمع آورى اطلاعات به بيش از 20 كلينيك

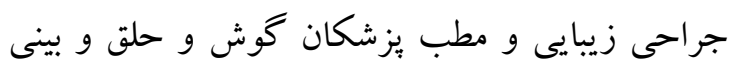

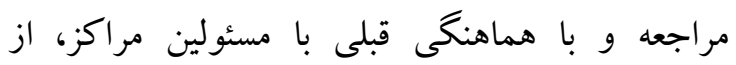

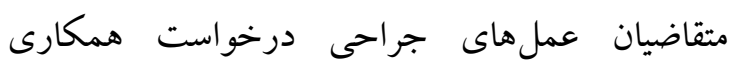
بهعمل آمده و به 315 نفر از متقاضيان عملهاى

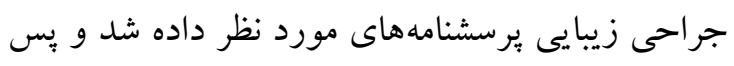

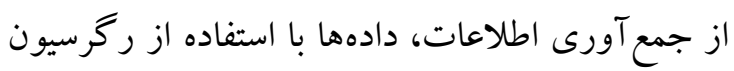
جند گانه مورد تحليل قرار گرفت.
بدن ديده نمىشود. آنها يا تغييرى را گزارش نمىدهند و يا از تغيير ايجاد شده رضايت ندارند (خواجهالدين و ايزدىمزيدى، 1391؛ رحيمى، دالبند و همكاران، 1392). از سوى ديخر مطالعات خانجانى، بابايور و ورئي صبا (1391) نشان داد كه ميان افراد متقاضى عمله داى داى جراحى زيبايى و افرادى كه تمايلى به اين كار ندارند

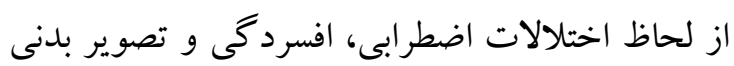
تفاوت معنادارى وجود دارد. بررسى تصوير تن در افراد از اين نظر حائز اهميت است كه تصوير ذهنى كه آنها از بدن خود دارند

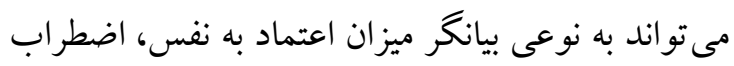

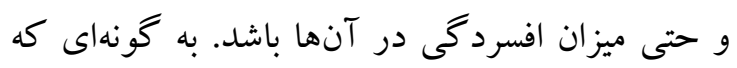
افر اد با تصوير بدنى منطبق تر با واقعيت، احتمال دارد از عزت نفس بهترى برخوردار باشند و كمتر دجار اضطراب و افسردگى شوند (فريحى و علييور، 1388). ويز گىهاى شخصيتى فرد مىتواند عوامل اكتساب تصوير تن را تحت تأثير قرار دهد. تصوير تن با في

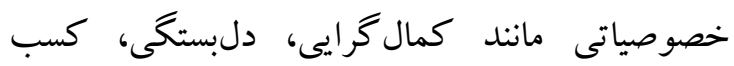

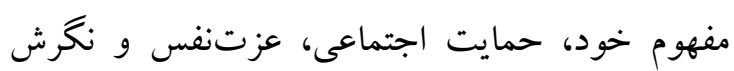
نسبت به نقشهاى جنسيتى ارتباط دارد (فرشيدىفر،

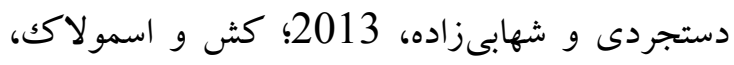
.2011

بررسى تصوير تن از منظر عوامل روانشناختى زيربنايى مانند خصوصيات شخصيتى كه در بس آن قرار دارد مى تواند به دركك دقيق تر و عميق تر آن منجر شود. از آنجا كه خصوصيات شخصيتى از زيربنايىترين و مهم ترين عواملى هستند كه مىتواند در تصوير بدنى افراد و تصميماتى كه در آينده براى بدنشان خواهند

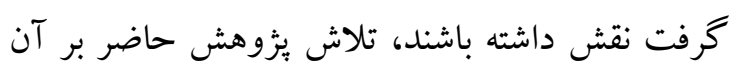

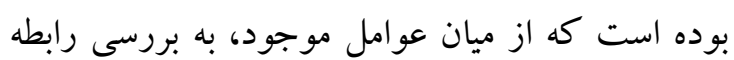
عوامل شخصيتى با تصوير تن بيردازد. 
0/88 و همسانى درونى زيرمقياس رضايتمندى از

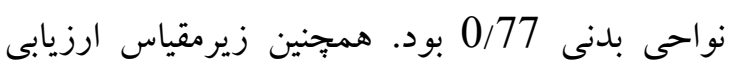

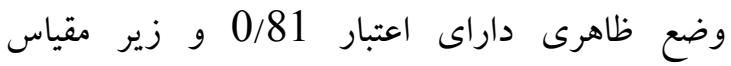
رضايتمندى از نواحى بدنى داراى اعتبار 0/86 بود.

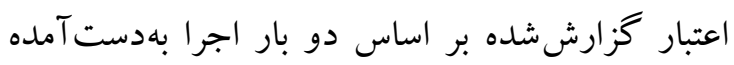
است (مكيان، اسكندرى و همكاران، 1389). ضرايب

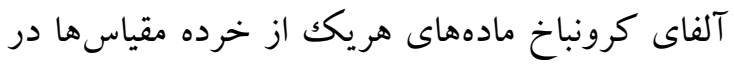
مورد يكك نمونه 217 نفرى از دانش آموزان به ترنيك

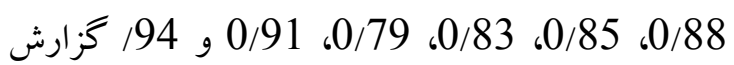

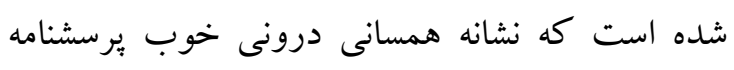
است (به نقل از صادقى صومعه عليايى، خدابخشى و

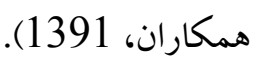

\section{آزمون קنج عامل شخصيت NEO: اين}

يرسشنامه توسط كاستا و مكك كريدر دو فرم 240 و

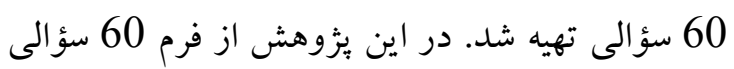

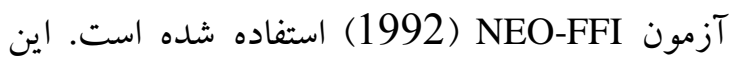

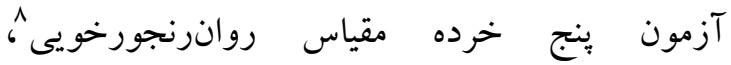

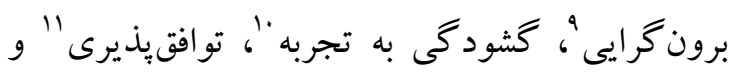

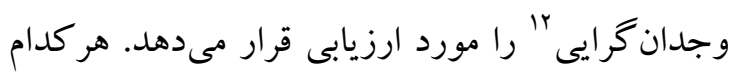

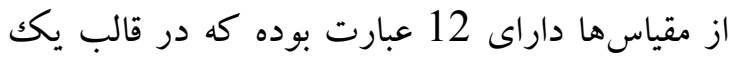

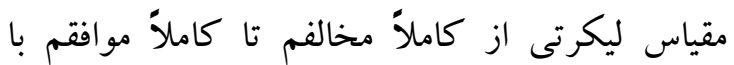

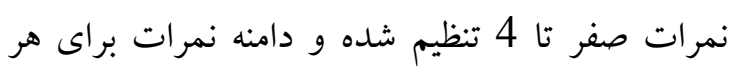

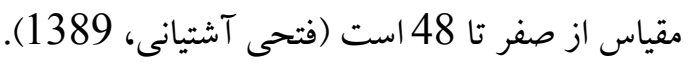
كيامهر (1381) يس از هنجاريابى اين آزمون در

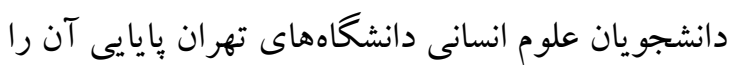

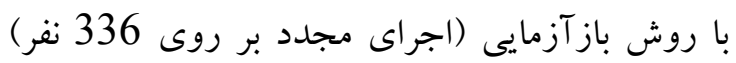

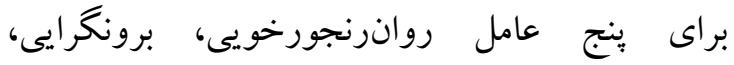

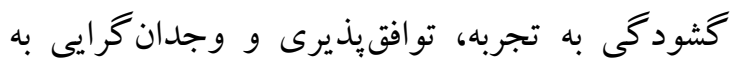
ترتيب 0/84، 0/82، 0/78، 0/65 و 0/86 و آلفاى

8 Neuroticism $(\mathrm{N})$

9Extraversion (E)

10Openness to experience $(\mathrm{O})$

11Agreeableness (A)

12Conscientiousness (C)
ير سشنامه روابط جندبعدى بدن - خود ': اين آزمون براى اولين بار توسط توماس. اف. كث در

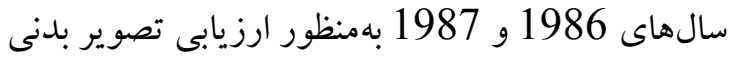
طراحى شد. در يُزوهش حاضر، نسخه بازنكرى شده (1997) استفادهشده است. شركت كنند كان در اين آزمون بايد به 46 گويه، بر اساس مقياس ليكرت

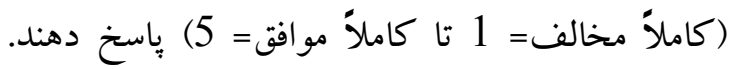
نمرات اين برسشنامه در دامنه 230-46 قرار مى گيرد. زير مقياسهاى اين آزمون شامل: ارزشيابى وضع

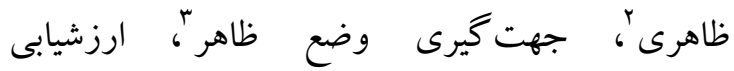

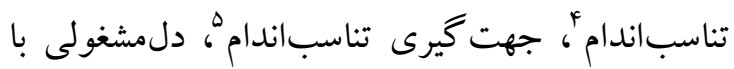

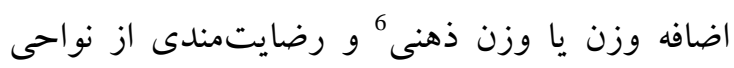
بدنى \است (زندا، 1388).

نقطهى برش اين ابزار، ميانخين است. نمرات بالاتر

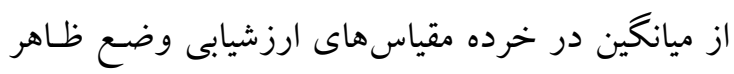
و رضايتمندى از قسمتهـاى مختلف بدن به ترتيب نسشان دهنـده احساس جـذابيت فيزيكـى و رضـايت بـالا از وضـعيت ظـاهرى و رضـايت از قسمتهاى

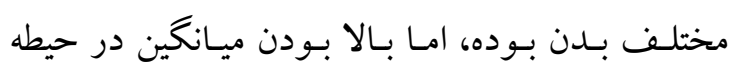

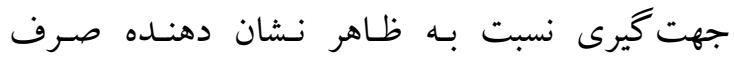
زمـان، تلاش و انرزى ذهنى قابل توجهى بـراى ظـاهر و جـابيت بوده و نشاندهنده رضايت بِايين از تصوير بــنى در اين حيطهها است. همجنـين نمـرات بـالاتر از ميـانگين در حيطه مشغوليت فكرى بـا اضـافه وزن، نساندهنده رضايت بايين و نكرانى و اضطراب بيشتر در مورد وزن و جاقى است (كش، 2000). در مطالعهاى كه درسال 1994 توسط كث انجام شد، همسانى درونى زيرمقياس ارزيابى وضع ظاهرى

1 The Multidimensional Body-Self Relation Questionnaire

2Appearance evaluation (AE)

3 Appearance orientation (AO)

4Fitness evaluation (FE)

5Fitness orientation (FO)

6Subjective weight ( SW)

7 Body areassatisfaction(B AS) 
اين بثزوهش از طريق برسشنامهاى خود كزارشى تهيهشده است، بنابراين لازم به ذكر است كه تمامى افراد با رضايت كامل در اين يُزوهش شر كت كردهاند. همجنين از آنجا كه دادههاى جمع آورى شده به

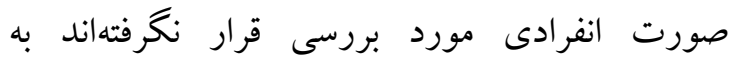
متقاضيان اطلاع داده شد كه نيازى به ذكر نام و خصوصيات فردى آنها نيست و صرفاً ذكر اطلاعات جمعيت شناختى كفايت مى كند.

\section{يافتهها}

بررسى خصوصيات جمعيت شناختى دادههاى جمع آورىشده در بزوهش حاضر در جدول 1 آورده

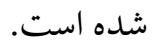

كرونباخ را براى اين عوامل به ترتيب 0/79، 0/73،

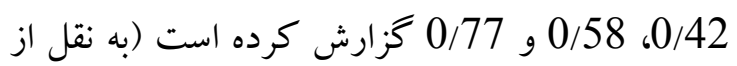
فخرائى و همكاران، 1392؛ عرب و همكاران، امانالهىفرد (1384) بايايى اين آزمون را به روش باز آزمايى براى بنج عامل به ترتيب 0/86، 0/80،

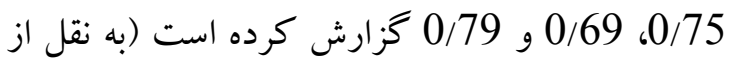
سروقد و همكاران، 1390). بس از جمع آورى دادهها و وارد نمودن آنها در

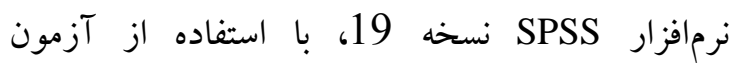

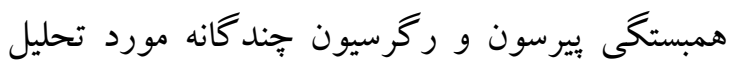
قرار گرفت. از آنجا كه اطلاعات جمع آورى شده در

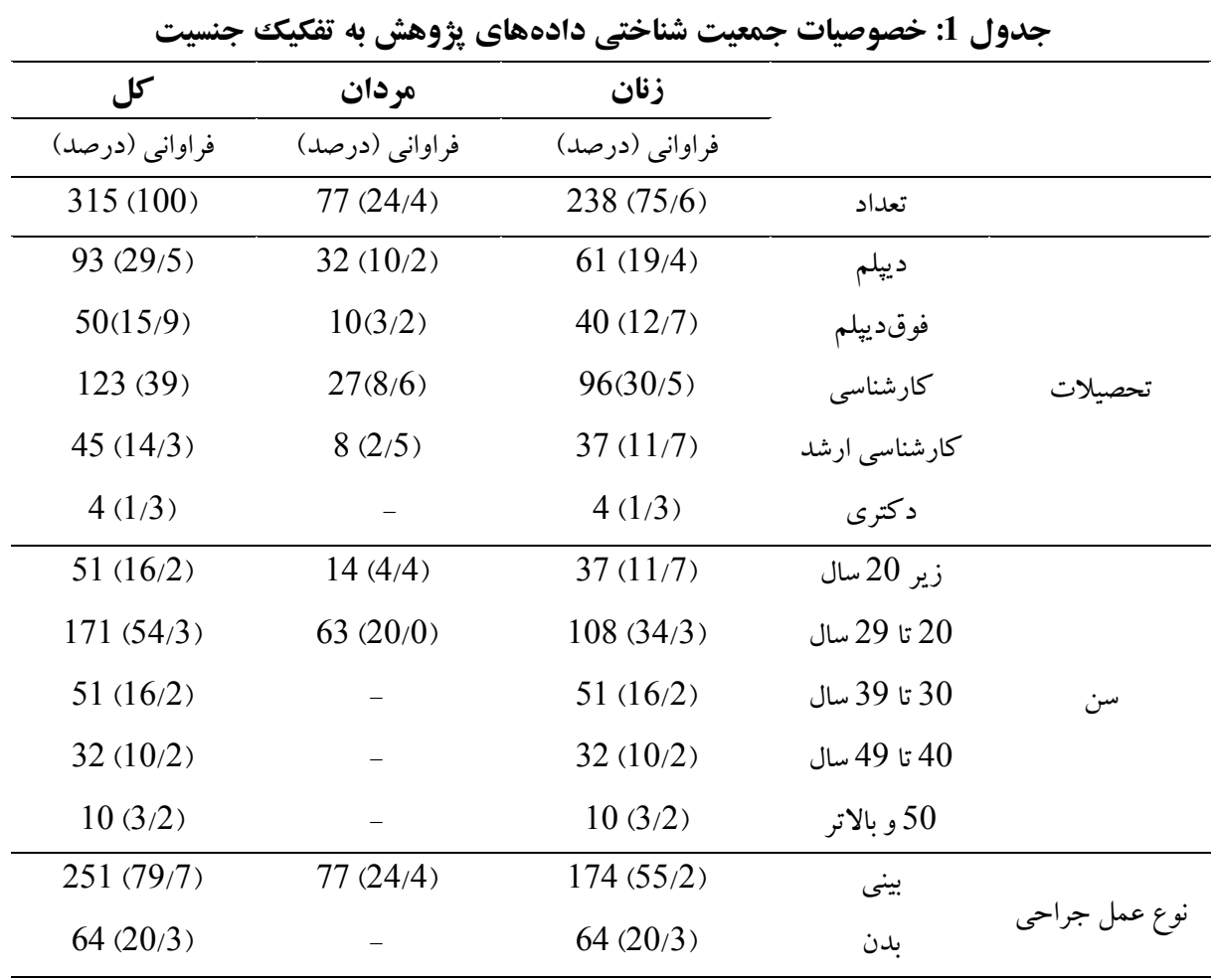

كه از اين 39 درصد، 30/5 درصد به زنان و 8/6 درصد به مردان اختصاص دارد. همجنين 54/3 درصد از افراد شركت كننده در اين يزوهش در بازه سنى بين
با عنايت به جدول 1 شركت كنندگان داراى تحصيلات كارشناسى، 39 درصد از كل نمونه و فراوانترين طبقه تحصيلى در بين 315 آزمودنى هستند 
فراوانى ذكرشده در قسمت عمل جر احى بدن مربوط به زنان بوده و از جر احىهاى بينى 24/4 درصد به مردان

و 55/2 درصد به زنان اختصاص دارد.
20 تا 29 سال قرار داشتند. در خصوص نوع عمل جراحى تمام متقاضيان مرد در اين يثوهش به منظور انجام عمل جراحى بينى مراجعه كرده بودند، بنابراين

جدول 2: ميانكين و انحر اف استاندارد متغيرهاى ثخوهش به تفكيك جنسيت

\begin{tabular}{|c|c|c|c|}
\hline كل - - ال & مردان & 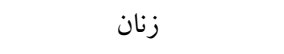 & متغير ها \\
\hline ميانخين (انحراف استاندارد) & ميانخين (انحر اف استاندارد) & ميانگين (انحراف استاندارد) & \\
\hline $21 / 42(8 / 50)$ & $21 / 40(9 / 81)$ & $21 / 34(8 / 06)$ & روانرنجورخويى \\
\hline $26 / 68(5 / 71)$ & $25 / 78(5 / 62)$ & $26 / 97(5 / 71)$ & برونگرايى \\
\hline $26 / 53(5 / 33)$ & $27 / 32(5 / 54)$ & $26 / 27(5 / 24)$ & كشود گى به تجربه \\
\hline $27 / 52(5 / 42)$ & $26 / 25(5 / 47)$ & $27 / 94(5 / 35)$ & توافت يذيرى \\
\hline $33 / 17(7 / 16)$ & $36 / 97(7 / 24)$ & $31 / 93(7 / 02)$ & وجدان گرايى \\
\hline $46 / 57(6 / 36)$ & $48 / 77(5 / 47)$ & $45 / 86(6 / 46)$ & ارزيابى وضع ظاهرى \\
\hline $24 / 39(3 / 78)$ & $26 / 43(3 / 12)$ & $23 / 74(3 / 75)$ & جهت گيرى به ظاهر \\
\hline $44 / 42(6 / 92)$ & $50 / 25(6 / 92)$ & $42 / 53(5 / 79)$ & ارزيابى تناسب \\
\hline $10 / 78(2 / 38)$ & $12 / 30(1 / 61)$ & $10 / 29(2 / 39)$ & جهت گيرى تناسب \\
\hline $6 / 43(1 / 52)$ & $6 / 17(1 / 27)$ & $6 / 52(1 / 59)$ & وزن ذهنى \\
\hline $31 / 47(6 / 09)$ & $33 / 09(4 / 04)$ & $30 / 95(6 / 54)$ & رضايتمندى از نواحى بدنى \\
\hline
\end{tabular}

زيبايى رابطه معنادار وجود دارد. در اين ميان مىتوان به رابطه معنادار و منفى روانرنجورخويى با ارزيابى ريى ظاهرى (r=-0/132) و رضايتمندى از نواحى بلدنى

$$
\text { (r=-0/231) }
$$

شاخصهاى توصيفى براى متغيرهاى يُزوهش به

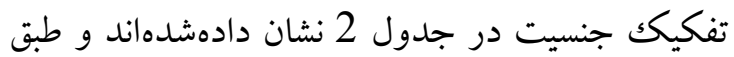
ضرايب همبستخى بيرسون كه در جدول 3 نشان داده شده است بين تعدادى از ينج عامل شخصيت و خرده

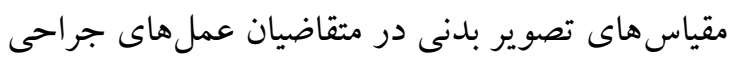

جدول 3: ضرايب همبستىى خرده مقياسهاى هنج عامل شخصيت ابعاد تصوير بدنى

\begin{tabular}{|c|c|c|c|c|c|c|}
\hline رضايتمندى از & وزن ذهنى & جهت گيرى نسبت به & تناسباندام & نهبت گيرى به ظاهر & ظاهرى ارئى & متغير ها \\
\hline$-0 / 231^{\text {** }}$ & $0 / 043$ & $-0 / 079$ & $-0 / 039$ & $-0 / 032$ & $-0 / 132^{*}$ & روانرنجورخويى \\
\hline $0 / 203^{* *}$ & $0 / 029$ & $-0 / 009$ & $0 / 069$ & $-0 / 034$ & $0 / 132^{*}$ & برونكر ايى \\
\hline $0 / 166^{* *}$ & $0 / 059$ & $0 / 071$ & $0 / 082$ & $0 / 040$ & $0 / 211^{* *}$ & گشود گى به تجربه \\
\hline $0 / 162^{* *}$ & $0 / 101$ & $-0 / 080$ & $0 / 166^{* *}$ & $-0 / 190^{* *}$ & $0 / 100$ & توافقيذيرى \\
\hline $0 / 201^{* *}$ & $-0 / 133^{*}$ & $0 / 178^{* * *}$ & $0 / 173^{* *}$ & $0 / 215^{* *}$ & $0 / 246^{* *}$ & وجدان گرايى \\
\hline
\end{tabular}

* معنى دارى در سطح 0/05

** معندارى در سطح 0/01 
4). همانطور كه در جدول 4 مشاهده مىشود، طبق مناسبترين مدل به دست آمده از تحليل ركرسيون يس از حذف متغيرهايى كه سهم معنادارى در بيشبينى

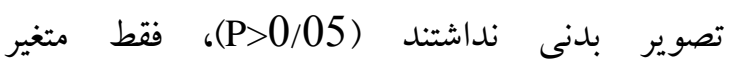

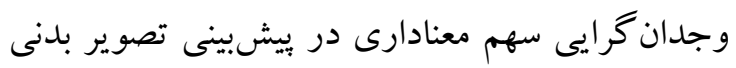

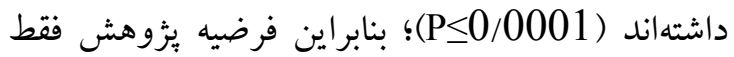
در ارتباط با متغير وجدان گرايى تأييد كرديد و در ارتباط با متغيرهاى ديخر تأييد نشد. متغير وجدان خرايى (R=0/004) مىشود اين متغير با داشتن سطح معنىدارى پايينتر از

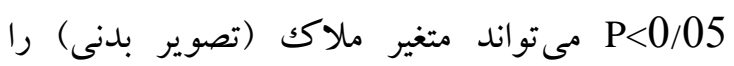

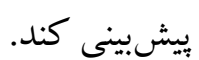

از سوى ديخر برونگ ايى و گشودگى به تجربه با ارزيابى ظاهر و رضايتمندى از نواحى بدنى رابطه

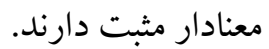
توافقيذيرى با جهت گيرى به ظاهر رابطه معنادار منفى و با ارزيابى تناسب و رضايتمندى از نواحى بدنى رابطه مثبت معنادار دارد. وجدان گرايى نيز در سطح (p<0/001) با تمام ابعاد تصوير بدنى رابطه

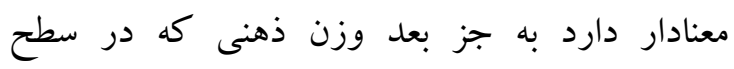
معنىدارى (p/05) 0/p) رابطه منفى با اين خرده مقياس دارد. براى بيشبينى تصوير بدنى بر پِايه پينج عامل

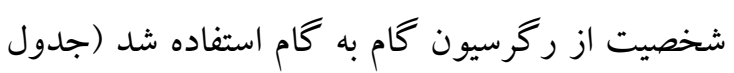

جدول 4: خلاصه مدل ركرسيون كام به كام مقياسهاى باورهاى غير منطقى بر تصوير بدنى

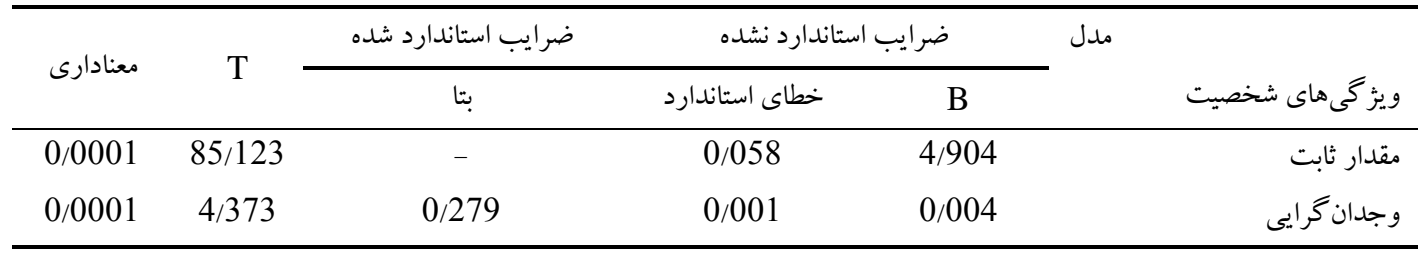

يُزوهش هاى مشابه بيشتر بوده است. به نظر مى رسد اين تفاوت نشاندهنده افزايش تقاضا و ترويج انجام عملهاى جراحى زيبايى در ميان مردان است كه با نتايج يزوهش احيايى و همكاران (1392) و شريفى و

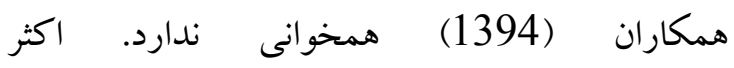
شر كت كنند كان در دامنه سنى 20 تا 29 سال (54/3 (1) درصد) و در مقطع تحصيلى ليسانس (39 درصد) قرار دارند كه با نتايج يثزوهش قادرزاده و همكاران

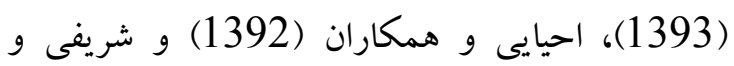
همكاران (1394) همخوان است. بر اساس يافته هاى اين هئوهش متقاضيان عمل جراحى زيبايى بينى 251

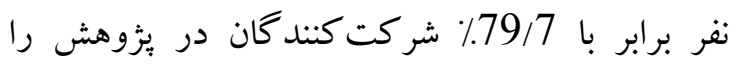

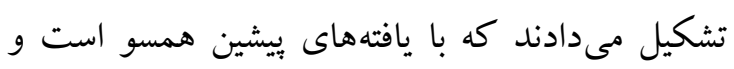

همجنين با توجه به ستون بتا مى توان گفت با تغيير

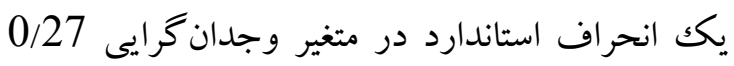
انحراف استاندارد تغيير (در جهت مستقيم) در تصوير بدنى ايجاد مى شود. بحث و نتيجه كيرى هدف اين يزٔوهش بيشبينى تصوير بلدنى بر اساس ينج عامل شخصيت در متقاضيان عملهاى جراحى زيبايى در شهر اصفهان بود. بر اساس يافتهاى جمعيت شناختى اين بثوهش، زنان بيشتر از مردان تمايل دارند عمل هاى جر احى زيبايى انجام دهند. با اين وجود تعداد

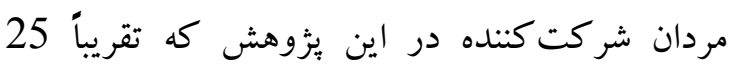
درصد از شركت كنندها را تشكيل مىدهند ازئ 
قالبهاى ذهنى مشخص و غير قابل انعطاف دارند، به همين دليل تصور غير واقعبينانهاى از خود دارند، بنابر اين به نظر مىرسد وجدان گر ايى بالا ميان متقاضيان

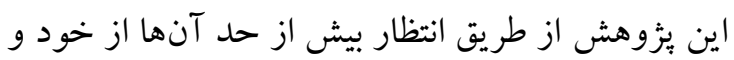
تمايل آنها به سرزنش كردن خود در در شرايطى كه ظاهرشان با آن كليشه هاى ذهنى انطباق ندارد قابل تبيين باشد. به خاطر وجود ويز گى هايى مانند وجدان گركائي بالا و داشتن الكوهاى رفتارى وسواس اجبار، زمانى كه ونه به اين نتيجه مىرسند كه نياز دارند ظاهر خود را تغيير دهند، براى رسيدن به هدف خود اقدام و پافشارى

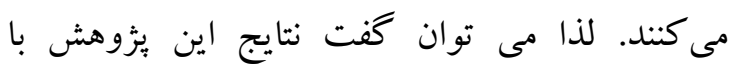
يثزوهش مسعودزاده و همكارانش (1388) نيز همسو مى باشد كه نشان دادند افراد متقاضى عمل جراحى زيبايى نمرات بيشترى در دو سر طيف وجدان گر ايى به

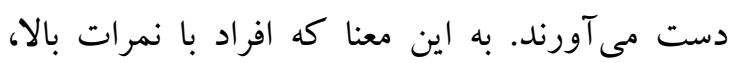
افرادى با افكار وسواسى و با تمايل بسيار براى كنترل

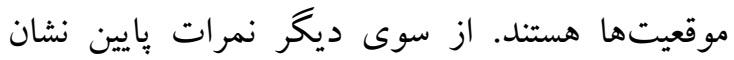
دهنده نبود باريكك بينى و دقت نظر در اين افراد است كه با نتايج ئزوهش حاضر همخوان نيست. در مقابل، جاوان و همكاران (2006) در نتايج خود به اين

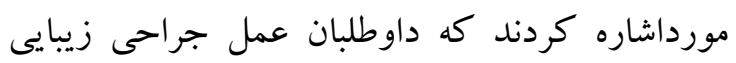
نسبت به گروه شاهد نمرات كمترى در اين خرده مقياس كسب كردهاند. ساير خرده مقياسهاى ينج عامل شخصيت با وجود آنكه با خرده مقياسهاى تصوير بلدنى رابطه معنادار دارند، اما توانايى بيشبينى كردن آنها را ندارند. روانرنجورخويى با ارزيابى ظاهر و رضايتمندى از

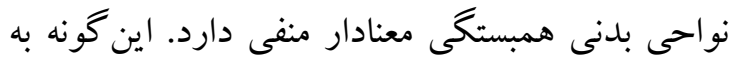
نظر مىرسد كه افراد روانرنجور نارضايتى بيشترى از تصوير بدنى خود دارند و تمايل آنها به انجام عمل جراحى زيبايى بيشتر است كه اين با نظر سوامى و

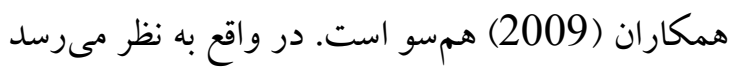

يكى از مواردى است كه در تحقيقاً قبلى ايران را به عنوان پايتخت جراحى بينى در دنيا مطرح ساخته است

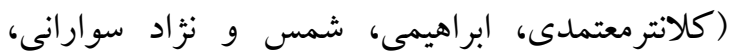
.(2016

نتايج تحليل رگرسيون گام به گام براى پاسخ به اين فرضيه نشان داد كه از ميان بنج خرده مقياس ينج عامل بزرگك شخصيت، تنها وجدان گرايى به شكل معنادارى

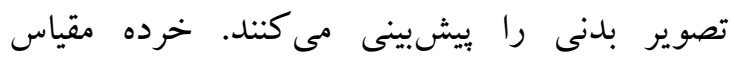
وجدان كرايى با بالاترين ميزان تأثير كذارى بر تغييرات

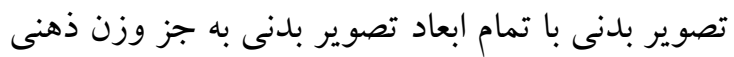

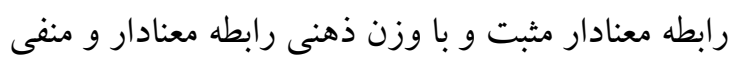
دارد. نتايج يُزوهش حاضر با يزوهش سوامى و و همكاران (2009) همسو است و نشان مىدهد كه افراد با وجدان گرايى بالا بيشتر متقاضى عملهاى جراحى

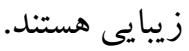

از سوى ديخر نمرات بالا در خرده مقياس وجدان گرايى از دو جنبه مثبت و منفى برخوردار است.

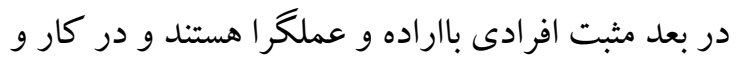
حرفه خود موفقيت زيادى كسب مى كنند و در بعد منفى رفتارهايى مانند ايرادگيرىهاى فراوان، افكار وسواسى - جبرى و بافشارى بسيار زياد در زمينه انجام

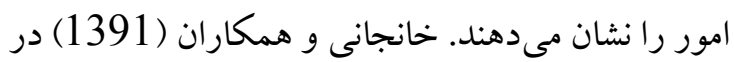
مطالعه خود جهت مقايسه وضعيت روانى و تصويرتن متقاضيان جراحى زيبايى با افراد غيرمتقاضى، محب و همكاران (1388) در مطالعه مقايسهاى اختلالات شخصيت در ميان طالبان جراحى زيبايى و افراد عادى و نيز قلعهبندى و ابراهيمى (1383) در بررسى الكوهاى شخصيتى متقاضيان جراحى زيبايى بينى مجموعا به اين نكته اذعان داشتهاند كه متقاضيان عملهاى جراحئى زيبايى بيشتر از جامعه عادى داراى ويزگیى شخصيتى وسواسى- اجبارى، خودشيفته و نمايشى

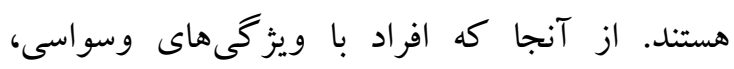


داد. يزؤهش مسعودزاده و همكاران (1388) نيز به اين

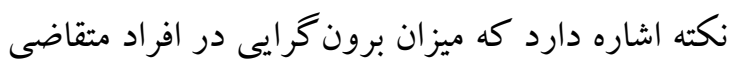
عملهاى جراحى زيبايى نسبت به گروه شاهد بيشتر

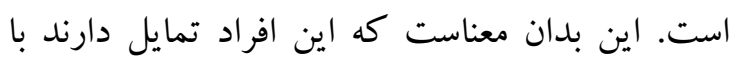
محيط اطراف خود بيشتر تعامل كرده و روابط اجتماعى

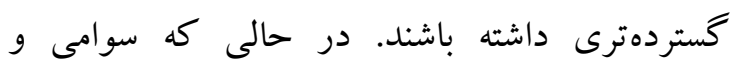

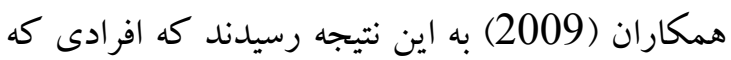
درون كرا هستند از ظاهر خود ارزيابى منفىترى دارند، بنابراين بيشتر احتمال دارد كه اقدام به انجام عمل جراحى زيبايى كنند. خرده مقياس گشودگى به تجربيه با خرده مقياس ارزيابى ظاهرى و رضايتمندى از نواحى بلدنى رابطه مثبت و معنادار دارد. در مقابل اين نتايج، نتايج يثوهش پاوان و همكارانش (2006) و كُشنى و همكاران

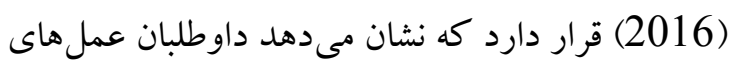
جراحى زيبايى در مقايسه با گروه شاهد نمرات كمترى در خرده مقياس گشودگى به تجربه به دست آوردند.

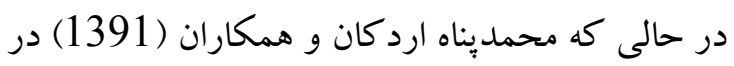
يزٔوهشى تحت عنوان صفات شخصيت و سبككهاى دفاعى در افراد داوطلب جراحى زيبايى و مسعودزاده و همكاران (1388) در مقايسه الخوهاى شخصيتى و ونرئ وضعيت سلامت عمومى متقاضيان جراحى زيبايى بينى

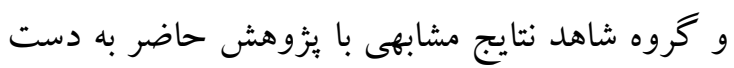

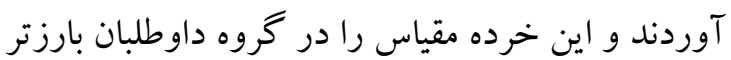
از گروه شاهد يافتند. به نظر مىرسد كهد اين اين افراد هرجه ارزيابى بهترى از ظاهر خود داشته باشد، بيشتر به داشتن روابط اجتماعى تمايل دارد و يذيرش افكار جديد و

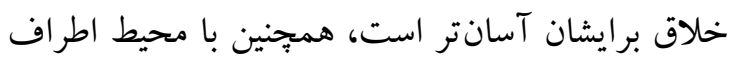
خود نيز مهربانتر هستند. و در نهايت خرده مقياس توافق يذيرى با ارزيابى مثبت از تناسب اندام و رضايتمندى از نواحى بلدنى تهري رابطه مثبت و با جهت گيرى نسبت به ظاهر رابطه منفى
افرادى كه ثبات عاطفى و هيجانى كمتر و استعداد بيشترى براى تجربه كردن احساسات ناخوشايند دارند، ظاهر خود را منفى تر ارزيابى مى كنند.

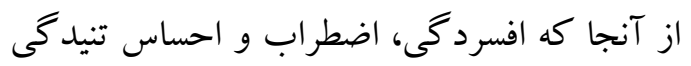
جزئى از زير مقياسهاى روانرنجورخويى به شمار

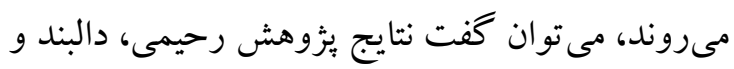

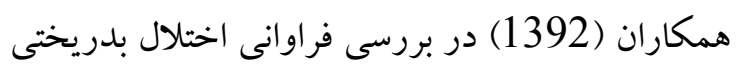

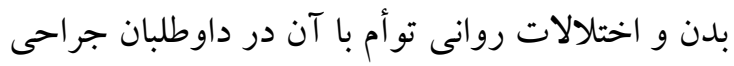

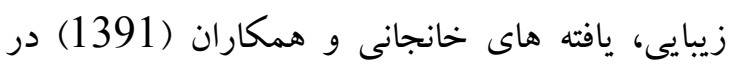
مقايسه وضعيت روانى و تصويرتن متقاضيان جراحى زيبايى با افراد غيرمتقاضى و هِاشا و همكاران (1388) در مقايسه تصوير بدنى،شاخص حجم بدنى، سلامتى

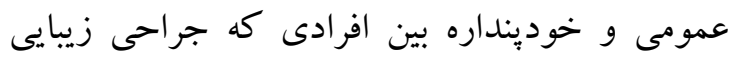
انجام دادند، افر اد متقاضى جراحى زيبايى و افراد عادى شهرستان بهبهان اين امكان را فراهم مى كند تا استباط نمود كه وجود احتمالى اضطراب اجتماعى توأم با جسمانى سازى، افسرده خويى و مجموعه اختلالات اضطر ابى در داوطلبان جراحى زيبايى همسو با يافته هاى

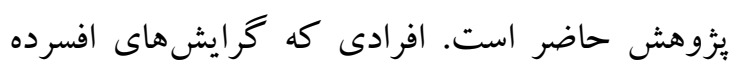
خويى دارند بيش از ساير افراد نخرش منفى نسبت به آهرى

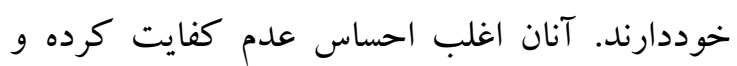
بيشتر از افراد بهنجار خود را در ابعاد مختلف جسمانى و روانى نالايق تصور مى كنند. همين نخرش منفى، همراه با ساير عوامل مى تواند باعث تمايل به تغيير ايجاد كردن در ظاهرشان توسط جراحى زيبايى شود تا بدين وسيله از احساس منفى خود بكاهند. اين در حالى است كه يافتهاى مسعودزاده و همكارانش (1388) نشان مىدهد متقاضيان عملهاى جراحى زيبايى نسبت به به

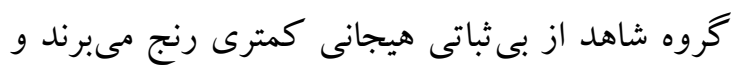
در مقابل استرس تحمل خويى دارند. برونغرايى در اين :ثزوهش با ارزيابى ظاهرى و و رضايتمندى از نواحى بدنى رابطه معنادار مثبت نشان 
تبديل شده و انجام آن به نوعى تعيين كننده جايگاه

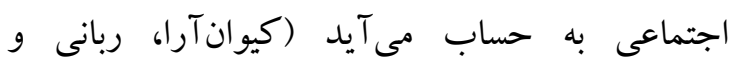
زيانيور، 1389؛ ميرساردو، كلدى و عطايى، 1389). هرجند اخيراً مطالعاتى نيز به اين نكته اشاره دارند كه

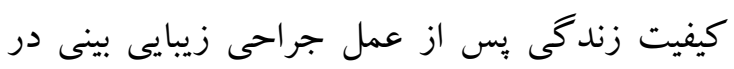
جمعيت ايرانى كاهش مى يابد كه علت آن مىتواند به خطاهاى بزشكى و نحوه انجام عمل جراحى نيز مرتبط باشد (محمدشاهى، بور رضا، عروج لو، محمودى و

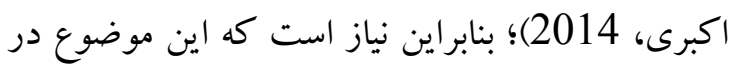
بعدى گستردهتر، هم از ديد گاه روانشناختى و هم از منظر جامعهشناختى موردمطالعه و بررسى دقيق ترى قرار

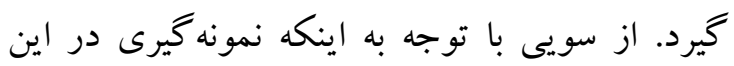
يثزوهش به صورت تصادفى نبوده است لذا در تعميم نتايج بايد جانب احتياط رعايت شود و در بزوهش هاى

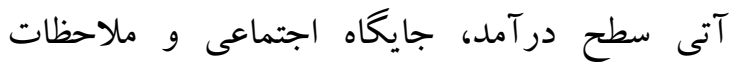
فرهنگى نيز در گروههاى نمونه مورد عنايت قرار داده

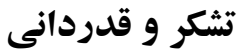

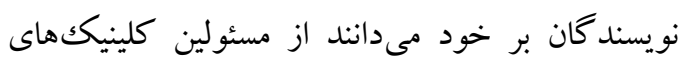
جراحى زيبايى شهر اصفهان و مراجعينى كه با بزوهشكران همكارى نمودند تشكر نمايند.
نشان داده است. نتايج يُووهش سوامى و همكاران (2009) نيز به نوعى با نتايج حاضر همسو هستند زيرا نشان دادند افراد با توافق بذيرى و ساز گارى بيشتر، كمتر احتمال دارد اقدام به انجام عمل جراحى زيبايى كنند و اين مىتواند عدم ييشبينى تصوير بلدنى در متقاضيان را توجيه مى كند. محمديناه اردكان و و همكاران (1391) در بررسى صفات شخصيت و سبكهاى دفاعى در افراد داوطلب جراحى زيبايى،

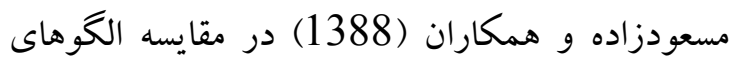
شخصيتى و وضعيت سلامت عمومى متقاضيان جراحى مانى زيبايى بينى و گروه شاهد و باوان و همكاران (2006) در بررسى شخصيت و خلقوخو در جراحىهاى ״بلاستيك در ايتاليا نشان دادند كه داوطلبان عملهاى جراحى نمرات توافقيذيرى كمترى نسبت به گروه شاهد داشتند كه خود نشاندهنده اتفاق نظر و همبستخى لهري كمتر و خودرأيى و فردگر ايى بيشتر در اين افراد است. تفاوتى كه ميان نتايج اين يُزوهش با بُزوهش هاى

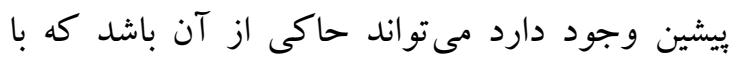
افزايش روزافزون عملهاى جراحى و كذشت زمان،

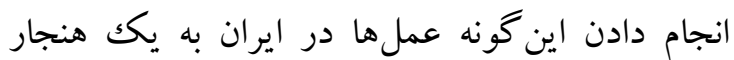
اجتماعى تبديلشده و از طرف جامعه مورد بذيرش قرار كرفته است و مطالعات جامعهشناختى نيز ابراز

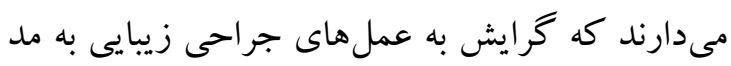




\section{References}

Ahyaee, F. A., Latifi, A., Bakhtiari, M., Hasanpoor, S. A., Shariati, N., Delpishe, A., \& Etemad, K. (2013). Epidemiologic study of the causes of cosmetic nose surgery in Tehran: Medicine and cultivation, 22(3),9-16.

Arab, A., Azkhosh, M., Farhoodian, A., Dolatshahi, B. \& Farzi, M. (2011). Comparison of personality characteristics of opiate dependent male and methamphetamine dependent male. Journal of Rehabilitation, 12 (5),14-20.

Asadi, M., Salehi, M., Sadoughi, M., \& Afkham Ebrahimi, A. (2013). Self-esteem and physical appearance before and after cosmetic nose surgery. Psychiatry and Clinical Psychology of Iran, 19 (1), 33-28.

Baniasadi, H. (2012). Effect of cosmetic nose surgery on the body image of women in Kerman. Journal of Skin and Beauty, 3 (4), 194-201.

Bolboli, L.\& Habibi Rajabi, A. (2013). The effect of increasing exercise hours on the body image, body mass, and social anxiety in students. School Psychology, 2 (2), 29-43.

Cash, T. (2000). The Multidimensional Body-Self Relations Questionnaire. MBSRQ User's Manual. Third Revision, January.

Cash, F. T. \& Smolak L. (2011). Body image: A handbook of science, practice, and prevention. Second edition.New York: The Guilford press.

Fakhraei, N., Khanjani, Z. \& Badri, R. (2013). Investigation of personality traits in addicted and normal people according to gender. Journal of Rehabilitation, 14 (1), 8-16.

Farihi, Sh., Alipoor, A. \& Latifi N. (2009). Investigating the relationship between perfectionism and depression with mediating role of body image in female volunteers in cosmetic surgery. Master's thesis, Payame Noor University of Tehran, Faculty of Literature and Human Sciences.

Farshidfar, Z., Dastjerdi, R. \& Shahabizadeh F. (2013). Acceptance of
Cosmetic Surgery: Body Image, Self Esteem and Conformity. Procedia - Social and Behavioral Sciences: 84, 238 - 242.

Fathi Ashtiani A. (2012). Psychological tests: personality assessment and mental health. Tehran: Be'sat publishing.

Feusner, J. D., Townsend, J., Bystritsky, A., \& Bookheimer, S. (2007). Visual information processing of faces in body dysmorphic disorder. Archives of General Psychiatry, 64, 1417-1425.

Fisher, S. (1990). The evolution of psychological concepts about the body. In T. F. Cash \& T. Pruzinsky (Eds.), Body images: Development, deviance and change (pp.3-20). New York: Guilford Press.

Ghaderzade, A., Khaleg panah, K. \& Khazaee, S.(2013). Analysis of Women's Experiences of Cosmetic Surgery (Qualitative Study of the Causes and Consequences of Cosmetic Surgery). Women's magazine in development and politics, 12(1), 1-20.

Ghale-bandi, F \& Ebrahimi, A. (2004). Personality Patterns of Applicants for Nose Surgery. Journal of Thought and Behavior, 9 (4), 4-10.

Golshani, S., Mani, A., Toubaei, S., Farnia, V., Sepehry, A.A.\& Alikhani, M. (2016). Personality and Psychological Aspects of Cosmetic Surgery. Aesthetic Plast Surg. 40(1):38-47. doi: 10.1007/s00266015-0592-7.

Kalantar Motamedi, M. H., Ebrahimi, A., Shams, A., \& Nejadsarvari, N. (2016). Health and Social Problems of Rhinoplasty in Iran. World Journal of Plastic Surgery, 5(1), 75-76.

Khajedin, N., \& Izadi Mazidi, S. (2012). Investigating the relationship between body image and tendency to perform rhinoplasty in female students. Jundishapur Scientific Journal, 11 (6), 665- 673.

Khanjani, Z., Babapour, J. \& Saba, G. (2012). Survey and 
comparison of psychological status and body image of applicants for cosmetic surgery with nonapplicants. Scientific and Research Journal of Medical Sciences University of Shahid Sadoughi of Yazd, 20(2),237- 248.

Kiwanara, M., Rabbani, R., \& Jianpoor, M. (2010). Social stratification and body correction: surgery as a social level symbol. Quarterly of the Women's Social Cultural Council, 12 (47), 73-98.

Makian, S., Eskandari, H., Borjali A. \& Godsi, D. (2010). Comparison of the Effect of Narrative Therapy and Diet on the Body Image Index of Women with Overweight and Obesity. Journal of Medical Sciences University of Shahid Beheshti, 5: 225-230.

Massoud Zadeh, A., Yousefi, M. \& Tirgari, A. (2009). Comparison of personality patterns and general health status of volunteers of cosmetic nose surgery and control patients. Shahed University Scientific-Research Bulletin, 16(82), 53-58

Mirsardo, T., Keldi A. \& Ataee B. (2010). Relationship between sociocultural factors and Tendency of women to Cosmetic Surgery in Karaj. Woman and family studies. 3 (10): 145-164.

Mohammadpanah Ardakan, A., Yaghoubi, H. \& Yousefi, R. (2012). Personality traits and defensive styles in volunteers of cosmetic surgery. Journal of Skin and Beauty, 3 (2), 72-82.

Mohammadshahi M., Pourreza, A., Orojlo, P.H., Mahmoodi, M., Akbari, F.(2014). Rhinoplasty as a medicalized phenomenon: a 25 center survey on quality of life before and after cosmetic rhinoplasty. Aesthetic Plast Surg, 38(4):615-9. doi: 10.1007/s00266014-0323-5.
Moheb, N., Hosseini Nasab D. \& Kolahi, P.(2009). A Comparative Study of Personality Disorders among the applicants of Cosmetic Surgery and Normal People. Woman and family studies, 1 (3), 91-106.

Parizadeh, H., Hassan Abadi, H., Mashhadi, A. \& Taghizadeh Kermani, A. (2012). Comparison of the Effectiveness of Existential Group Therapy and Reality Group Therapy in Solving the Problem of body image in mastectomized women. Journal of Women, Gynecology and Infertility, 15(23), 27-35.

Pasha, Gh., Naderi, F. \& Akbari, Sh. (2009) Comparison of body image, body mass index, general health and selfconcept among people who performed cosmetic surgery, people applying for cosmetic surgery and normal people in Behbahan city. New discoveries in psycology, 2 (7), 62-80.

Pavan, C., Vindigni, V., Mazzoleni, F., Gardiolo, M., Simonato, P., \& Marini, M. (2006). Personality, temperament and clinical scales in an Italian plastic surgery setting: what about body dysmorphic disorder?. International Juornal of Psychiatry in Clinical Practice,10 (2):91-96.

Rahimi, A., Dalband M., Shamsaee, F., \& Zarabian, M. (2013). Study of the frequency of body dismorphic disorder and psychiatric disorders associated with it in volunteers of cosmetic surgery. Psycho-Nursing Journal, 1(2), 70-78.

Sadeghi Some'e Olayali, R., Khodabakhshi Colaee, A., Akbari M.A.\& Calhorenia Golkar, M. (2012). Body image and self esteem: Comparison of two groups of women with breast cancer. Iranian Journal of Breast Diseases,2 and 3:16- 29.

Sarv-ghad, S., Meidokht Rezaei, A., \& Fadaee Dolat, A. (2011). The Relationship between Personality Characteristics and Coping Strategies with Subjective Well- 
Being of Teachers. New discoveries in Psycology, 5(16), 39- 23.

Sarwer, D., Crerand, B. \& Canice, E. (2004). Body image and cosmetic medical treatments. University of Pennsylvania School of Medicine, 1(1), 99-111.

Sarwer D.B. \& Spitzer J.C.( 2012). Body image dysmorphic disorder in persons who undergo aesthetic medical treatments. The American Society for Aesthetic Plastic Surgery, Inc. First published online: 1 November 2012.

Sharif, F., Anooshpour B., Mani, A., Zarshenas, L., Zare, N., \& Haghighatian, A. (2015). A Survey on the Characteristics of Personality of Patients Introduced to Cosmetic Surgery in Shiraz Hospitals Compared to Control Group in 2014-15. Electronic Journal of Nursing and Midwifery Society of Shiraz, 4 (2): 137147.

Smolak, L. (2004). Body image in children and adolescents: Where do we go fromhere? Body Image, 1:1528.

Swami, V., Chamorro-Premuzic, T., Bridges, S. \& Furnham, A.
(2009). Acceptance of cosmetic surgery: personality and individual difference predictors. Body Image, 6(1),7-13. doi: 10.1016/j.bodyim.2008.09.004. Epub 2008 Nov 28

Thompson J.K. \& Smolak L. (2009). Body image, Eating disorders, and obesity in youth: assessment, prevention, and treatment. American Psychological Association. Washington, DC. Second Edition

Zamani, N. \& Fazilatpour M. (2013). The Effect of cosmetic surgery on Selfesteem and Negative Image of Self. Journal of Medical Sciences University of Kerman, 20 (5),492-504.

Zeighami Mohamadi, Sh. \& Mojde F.(2012). Correlation between body mass index, mental image of the body and depression in women referring to Hazrat Ali Hospital in Karaj in 2009. New Care: A Journal of Nursing and Midwifery Faculty of Birjand University of Medical Sciences, 9 (1), 40-48.

Zhanda L. (2009). Personality tests. Translation of Besharat and Habib Nejad. Aeezh Publishing. 